\title{
Characterizing the Celery Genome with DNA-based Genetic Markers
}

\author{
Xiaofeng Yang and Carlos F. Quiros ${ }^{2}$ \\ Department of Vegetable Crops, University of California, Davis, CA 9.5616 \\ Additional index words. Apium graveolens, genome organization, RFLP, RAPD, methylation
}

\begin{abstract}
To characterize the celery (Apium graveolens $\mathrm{L}$. var. dulce, $2 \mathrm{n}=2 \mathrm{x}=22$ ) genome, 126 celery cDNA clones and 340 random 10-mer primers were used to generate restriction fragment-length polymorphism (RFLP) and randomly amplified polymorphic DNA (RAPD) markers between two cultivated types. Different abundance classes of the genomic sequences represented by the cDNA clones and the RAPD markers were observed. Most of the cDNA clones were singlecopy sequences, suggesting the true diploid nature of the celery genome. Nearly half of the 39 RAPD markers tested by Southern hybridization were multiple-copy sequences. Of the RAPD markers tested, $28 \%$ was single- and low-copy, and $26 \%$ was high-copy sequences. The polymorphism level of the cDNA clones was $23 \%$ when tested with four restriction enzymes (Eco RI, Eco RV, Hin dIII, and Hae III). A positive association was observed between RFLP level and the size of cDNA inserts or hybridized restriction fragments. Deletion, insertion, and base substitution were important in the formation of the RFLP markers. Eighty-two (23\%) of the 340 primers tested yielded useful RAPD markers, but only $3.8 \%$ of the amplified products were polymorphic. Base substitution may be the most important mechanism for the RAPD markers in celery. The RAPD fragments revealed no RFLP markers when tested by Southern hybridization, implying that RAPD markers are an important complement to RFLP markers in genomic mapping in celery. Random methylation of cytosine was determined in 5S rDNA on Bam HI and Hin dIII cutting sites that produced ladder patterns characteristic of tandem repeats.
\end{abstract}

Celery is a biennial species grown world wide. Bulk selection is a common practice for breeding of this predominantly crossedpollinated species (Quiros et al., 1986). There are three cultivated types: var. dulce (celery), var. rapaceum (celeriac), and var. secalinum (smallage) currently cultivated in different regions for different purposes. This species has been subjected to few genetic studies including inheritance of morphological and physiological traits (Emsweller, 1933; Pope and Munger, 1953a, 1953b; Townsend et al., 1946), male sterility (Quiros et al., 1986), cytogenetics (Hiroe, 1955; Murata and Orton, 1984), tissue culture (for review, see Orton, 1983), and transformation (Catlin et al., 1988).

A few molecular markers have been identified in celery. Arus and Orton (1984) reported eight isozyme markers. Quiros et al. (1987) identified four linkage groups including genes for annual habit, anthocyanin, and nine isozyme markers. Huestis et al. (1993) developed eight linkage groups based on 21 restriction fragment-length polymorphism (RFLP) markers, 10 isozyme markers, and 1 anthocyanin marker. A ladder pattern characteristic of tandem repeated arrays for $5 \mathrm{~S}$ rDNA on Hind111 digests was also observed by Huestis et al. (1993) in the celery genome. The 5S rDNA represents one of the most abundant gene families in eukaryotes (Lapitan et al., 1991) and has been characterized in many plants (Lagudah et al., 1989; Lapitan et al., 1991; Rafalski et al., 1982). The 18S-28S rRNA genes have been characterized in celery and no variation was found among cultivated types for the restriction sites surveyed and for the length of the complete repeat unit (Huestis, 1992).

The genome size of celery is relatively large, containing $3.0 \mathrm{pg}$ of DNA per haploid nucleus (E. Earle, personal communication),

Received for publication 11 Oct. 1994. Accepted for publication 30 May 1995. We thank Jinguo $\mathrm{Hu}$ and Gorden Huestis for advice and Vicent D'Antonio for technique assistance. This project is support by the California Celery Research Board. The cost of publishing this paper was defrayed in part by the payment of page charges. Under postal regulations, this paper therefore must be hereby marked advertisement solely to indicate this fact.

'Current address: Dept. of Food Science and Technology, Univ. of California, Davis, CA 95616.

${ }^{2}$ To whom reprint requests should be addressed. but little is known about its organization. The objective of this paper was to characterize the celery genome with RFLP and randomly amplified polymorphic DNA (RAPD) markers, as to the nature of its polymorphism, level of sequence duplication, and methylation of $5 \mathrm{~S}$ gene family.

\section{Materials and Methods}

Plant material. An $\mathrm{F}_{2}$ population of 90 plants was derived from a single self-pollinated $F_{1}$ plant obtained by crossing two land races, one of celeriac (PI16900), and an annual smallage (PI257228). The whole population was used for RAPD marker identification and only eight to nine individuals were used for RFLP marker screening. Since the original parental and $F_{1}$ plants were not available, five to ten individuals from each of the populations were bulked for the initial restriction enzyme-probe and RAPD polymorphism screening. The celery genome was subsequently characterized with the markers identified by the $\mathrm{F}_{2}$ population.

DNA extraction, enzyme digestion, and electrophoresis. Genomic DNA was isolated from 1 to $3 \mathrm{~g}$ of young leaf tissue following the method described by Hu and Quiros (1991). Twenty microgram of genomic DNA $\left(0.1 \mu \mathrm{g} \cdot \mu \mathrm{l}^{-1}\right)$ was digested with 8 to 10 units of different restriction enzymes at $37 \mathrm{C}$ for $2 \mathrm{~h}$. In the initial survey for polymorphic probes, eight restriction enzymes (Bam HI, $B g l$ I, Dra I, Eco RI, Eco RV, Hae III, Hind III, and Xho I) were used. Electrophoresis was conducted in $1 \mathrm{x}$ TAE (40 mM Tris-acetate, 1 mM EDTA) buffer at 35 volts $(1.4 \mathrm{~V} / \mathrm{cm})$ for $14 \mathrm{~h}$.

Polymerase chain reaction (PCR). A total of 340 arbitrary 10mer primers (sets A-P, and Z, Operon Technologies, Alameda, Calif.) was used for RAPD analysis (Yang and Quiros, 1993). PCR reactions were sensitive to experimental conditions such as the annealing temperature and concentrations of dNTP, template DNA, and $\mathrm{MgCl}_{2}$ To ensure the reproducibility of the RAPD markers, individuals of the $\mathrm{F}_{2}$ population were divided in four to five groups, and each group was amplified independently in a different PCR machine. Only the markers consistent in all of the operations were preserved.

Probe preparation. A total of 126 celery cDNA clones (Huestis 
et al., 1993) was screened for RFLP markers. The cDNA sequences were cloned in the PstI site of plasmid pBR322. Plasmids were isolated with Magic Minipreps Kit (Promega, Madison, Mich.), and the inserts were amplified by PCR with the pBR322 PstI primers (Promega). The primer sequences were 5'GCTAGAGTAAGTAGTT (clockwise) and 5'-AACGACGAGCGTGAC (counterclockwise). A 5S rDNA clone from wheat (Gerlach and Bedbrook, 1979) was also used. cDNA inserts and RAPD fragments were purified by using Magic Minipreps DNA Purification System and Magic PCR Preps Kit (Promega), respectively. Probes were labeled with ${ }^{32} \mathrm{P}$-dCTP using Multiprimer DNA Labeling System (Amersham, Arlington Heights, Ill.).

Southern hybridization. DNA was transferred to Zeta-Probe GT nylon membranes (Bio-Rad, Hercules, Calif.) following the manufacturer's alkaline blotting procedure. Membranes were prehybridized with a solution containing $0.25 \mathrm{M} \mathrm{Na}_{2} \mathrm{HPO}_{4}, 7 \%$ SDS, pH 7.2, in a shaker $(60 \mathrm{rpm})$ at $65 \mathrm{C}$ for 10 to $60 \mathrm{~min}$. After addition of radioactive labeled probes into the prehybridization solution, they were hybridized at $65 \mathrm{C}$ for 16 to $18 \mathrm{~h}$. Membranes

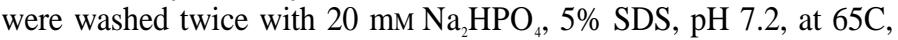
20 min each, then washed once with $20 \mathrm{~mm} \mathrm{Na}_{2} \mathrm{HPO}_{4}, 1 \%$ SDS, pH 7.2 , at $65 \mathrm{C}$ for 15 to $30 \mathrm{~min}$.

Determination of genomic copy number. A total of $100 \mathrm{cDNA}$ clones and 39 RAPD bands excised from gels were used as probes to estimate their genomic copy number. cDNA probes were hybridized to genomic DNA digested with each of the four restriction enzymes (EcoRI, EcoRV, HaeIII, and HindIII), and the lowest number of bands generated by the four enzymes was scored.

Determination of methylation site in $5 S$ gene family. Genomic DNA was digested by five restriction enzymes (AluI, BamHI, HindIII, MboI, and Sau3A) with different methylation sensitivities. HindIII and AluI are isoschizomers, as are MboI, BamHI and Sau3A. Southern hybridizations were subsequently carried out by using a 5 s gene probe (Huestis et al., 1993).

\section{Results}

Level of RFLP. For the initial screening, eight restriction enzymes (BamHI, BglI, DraI, EcoRI, EcoRV, HaeIII, HindIII, and Xhol) were used to determine which enzymes disclosed the highest level of polymorphism between the individuals of the two parental populations. Twenty-four probes were hybridized to the bulked parental DNA digested with each of the eight enzymes. The highest polymorphism level was found for EcoRV digestions, which showed differences in $21 \%$ of the probes tested, followed by Hind 111 with $17 \%$ polymorphism, and EcoRI and HaeIII, both yielding $13 \%$ polymorphism. The cumulative polymorphism frequency generated by all eight enzymes was $37 \%$, while that of the four most polymorphic enzymes (EcoRI, EcoRV, HaeIII, and HindIII) was $33 \%$. Because these four restriction enzymes produced about $90 \%$ of the total polymorphism, they were selected to digest the genomic DNA of the $\mathrm{F}_{2}$ population.

DNA from each of eight to nine individuals of the $\mathrm{F}_{2}$ population was used in the final screening for polymorphism. Thirty-three RFLP markers contributed by $29(23 \%)$ cDNA clones were disclosed. Eighteen RFLP markers were revealed by only one of the four restriction enzymes, and the remaining 15 were polymorphic in more than one enzyme digestion. When clones were polymorphic with more than one enzyme, only one enzyme digestion was used.

Although the four-base cutter (HaeIII) uncovered a relatively high level of polymorphism in the preliminary test using the bulked parental populations, as expected, it turned out to reveal much less polymorphism in the $\mathrm{F}_{2}$ population. The three most polymorphic six-base cutters (EcoRV, Hind111 and EcoRI) in the preliminary test also showed lower polymorphism in the $\mathrm{F}_{2}$ population (Table 1). The average sizes of hybridized restriction fragments generated by different enzymes varied too. They were 6.9, 10.2, 8.0, and 3.8 $\mathrm{kb}$ for EcoRI, EcoRV, HindIII, and HaeIII, respectively.

Possible association was discovered between the level of polymorphism and the average size of the hybridized restriction fragments (Table 1). RFLP also appeared associated with the sizes of cDNA probes. Table 2 shows that cDNA probes larger than $1.0 \mathrm{~kb}$ revealed about twice as much polymorphism as those of $1.0 \mathrm{~kb}$ or smaller.

Level of RAPD polymorphism. Of the 340 primers screened in the $\mathrm{F}_{2}$ population, $82(24 \%)$ primers yielded 128 polymorphic RAPD markers. On the average, each primer generated about 11 bands. Considering that 13 RAPD markers were codominant (Yang and Quiros, 1995) and each contributed two bands, the proportion of polymorphic bands was about 3.8\%. Of the 82 useful primers, $49(60.0 \%)$ generated only one marker per primer, 22 $(26.6 \%)$ generated two, eight $(9.8 \%)$ generated three, and three (3.6\%) generated four. The size of the RAPD markers ranged from $0.37 \mathrm{~kb}$ to $3.0 \mathrm{~kb}$, with an average of $1.1 \mathrm{~kb}$. A small proportion $(10 \%)$ of the RAPD markers were $0.5 \mathrm{~kb}$ or smaller. Most (71\%) ranged from $0.5 \mathrm{~kb}$ to $1.5 \mathrm{~kb}$. Fourteen percent of RAPD markers was between 1.5 and $2.0 \mathrm{~kb}$. Few RAPD markers (5\%) were larger than $2.0 \mathrm{~kb}$.

Genomic copy number represented by cDNA and RAPD markers. Of 100 cDNA clones tested, 59\% appeared to represent singlecopy sequences by showing just a single band for at least one enzyme digestion. Nineteen percent displayed two or three bands (Fig. 1). Copy number of these cDNA clones was ambiguous. They may or may not belong to single-copy sequences depending on the distribution of enzyme cutting sites. Fifteen percent showed four to six bands, and $7 \%$ showed seven to ten bands. The last two categories represented low-copy gene families.

The copy number distribution of the 39 RAPD bands, estimated from their hybridization to digested genomic DNA, was very different from that of RFLP markers (Fig. 1). Only 5\% showed a single band and $23 \%$ showed two to three bands, which corresponded to single- or low-copy sequences. Twenty-eight percent of RAPD bands hybridized to four to six fragments, and $18 \%$ hybridized to seven to ten fragments. These were multiple-copy sequence families representing a total of $46 \%$ of all the RAPD markers tested. Fifteen percent and $11 \%$ showed 11 to 20 and >20 fragments, respectively. These two categories represent high copy or repetitive sequences.

Methylation of $5 S$ rDNA. A ladder pattern was observed by Hind111 or AluI digestion in the celeriac parent, but was hardly observed in the annual smallage parent or the F, , when bulks of five plants from each population were used (Fig. 2). However, with prolonged exposure, the ladder was detected in annual smallage and the $F_{1}$, and each $F_{2}$ plant showed the ladder without segrega-

Table 1. Comparison of RFLP level and the average size of hybridized fragments of EcoRI, EcoRV, HaeIII, and HindIII.

\begin{tabular}{lcc}
\hline \hline $\begin{array}{l}\text { Restriction } \\
\text { enzyme }\end{array}$ & $\begin{array}{c}\text { Avg size (kb) of } \\
\text { hybridized fragments }\end{array}$ & $\begin{array}{c}\text { RFLP } \\
(\%)\end{array}$ \\
\hline HaeIII & 3.8 & 4.5 \\
EcoRI & 6.9 & 7.9 \\
HindIII & 8.0 & 12.3 \\
EcoRV & 10.2 & 18 \\
\hline
\end{tabular}




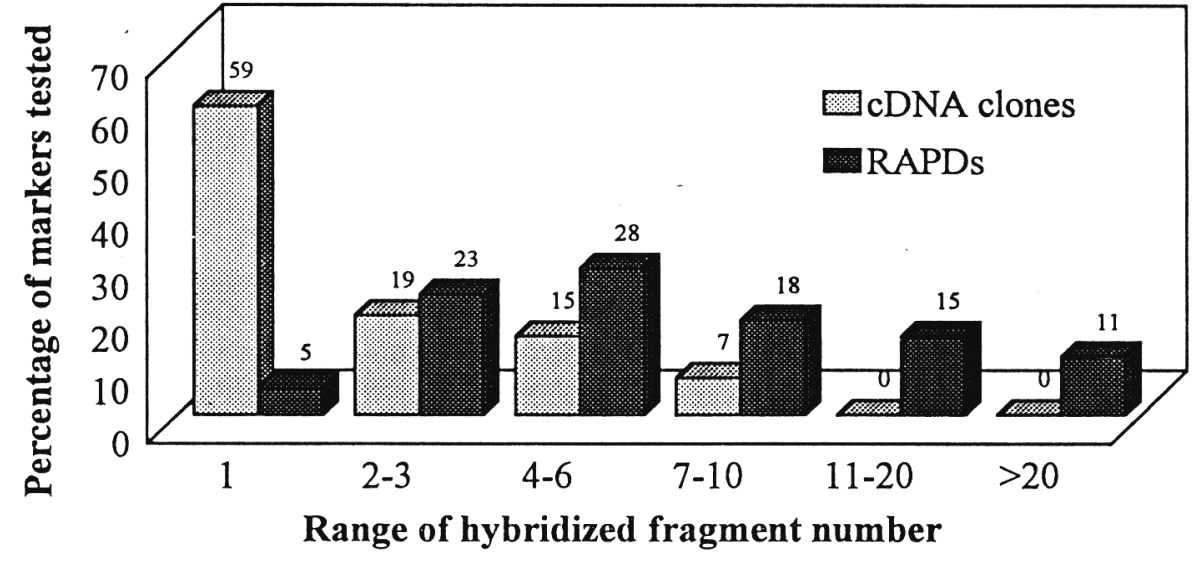

tion, although with variation of signal intensity (data not shown). The patterns generated with HindIII or AluI were not classical ladders in the sense that fragments were not evenly distributed, which may be because of Hind111 or AluI sites in spacer regions.

The restriction site of HindIII is AAGCTT, and the enzyme is sensitive to methylation at either 5' A or C. To determine which nucleotide is affected, genomic DNA was digested with AluI, which recognizes the internal four nucleotides of Hind111 site (AGCT) and is sensitive to A or C methylation. Identical ladders were produced with HindIII and AluI digests (Fig. 2), implying that the methylation site is in $\mathrm{C}$ instead of $\mathrm{A}$ in the sequence AGCT. Because HindIII is sensitive to methylation at 5' A (first A from 5' end) and AluI is sensitive to methylation at 3'A (second A) in the sequence AAGCTT, if methylation of either $\mathrm{A}$ is involved, the ladders generated by the two enzymes were unlikely to be identiCd.

Perfect simple ladders of $5 \mathrm{~S}$ were revealed with $\mathrm{BamHI}$ digestion, with a unit size of about $310 \mathrm{bp}$ (Fig. 2). The restriction site for BamHI is GGATCC, and the enzyme is sensitive to methylation at the 5' $\mathrm{C}$ site. To test whether the random methylation at the $5^{\prime} \mathrm{C}$ is the cause for the ladder pattern, $\mathrm{MboI}$ was used because it cuts the internal four bases (GATC) of the BamHI site but is insensitive to the $\mathrm{C}$ methylation. $\mathrm{MboI}$ cut all of the recognition sites and yielded a very strong single-unit fragment of $310 \mathrm{bp}$. This proved that the A in the restriction site was not methylated, because MboI is sensitive to methylation at the A site. Digestion with Sau3A, which has the same restriction site of MboI except that it is sensitive to $\mathrm{C}$ methylation, generated the typical ladder expected for the $5 \mathrm{~S}$ genes.

\section{Discussion}

\section{Genome constitution}

No repetitive sequences were found in the celery cDNA library clones. All of the cDNA hybridized to fewer than ten restriction fragments, and $93 \%$ of the cDNAs hybridized to one to five fragments. The cDNA clones that hybridized to single bands are most likely single-copy sequences. Those hybridizing to two or three bands can be considered as single- or low-copy sequences. Therefore, the proportion of single-copy sequences in the celery cDNA library ranges from $59 \%$ to $78 \%$, implying that celery is a true diploid species.

RAPD products represent a wide range of sequences from single to high copy. Of the amplified products tested, $28 \%$ was single- or low-copy sequences (one to three fragments by Southern hybridization). Nearly half (46\%) of the RAPD markers belong to multiple-copy sequences (four to ten fragments). Twenty-six
Fig. 1. Distribution of genomic copy number represented by the restriction fragment-length polymorphism and randomly amplified polymorphic DNA markers.

percent of the RAPD markers hybridized to more than ten bands and belong to highcopy sequences. In general, our study supports the conclusion drawn by Williams et al. (1993) that amplified RAPD products belonged to all abundance classes. Surprisingly, none of the 39 tested RAPD markers showed RFLP when hybridized to genomic DNA digested with each of the four restriction enzymes, implying that few polymorphisms revealed by the RAPD markers could be disclosed by RFLP markers in celery. In addition, genome sequences represented by RAPD markers are also different from those by RFLP markers in terms of different classes of abundance, especially when multiple-copy sequences are considered. In conclusion, RAPD markers may be an important complement to RFLP markers in genomic mapping of celery.

\section{Nature of the polymorphism}

RFLP markers. Polymorphism level is primarily determined by the relatedness of the cultivars used, but other factors such as genome size, duplications, transposable elements, reproductive system, and breeding approaches may affect variability as well. RFLP markers can occur either from point mutations at restriction sites or from deletions or insertions within restriction fragments. If a cDNA clone is polymorphic in only one of the four enzyme digestions, point mutation is inferred. Otherwise, if polymorphism is found in two or more enzyme digestions, deletion or insertion is more likely to be the reason (McCouch et al., 1988). Of the 29

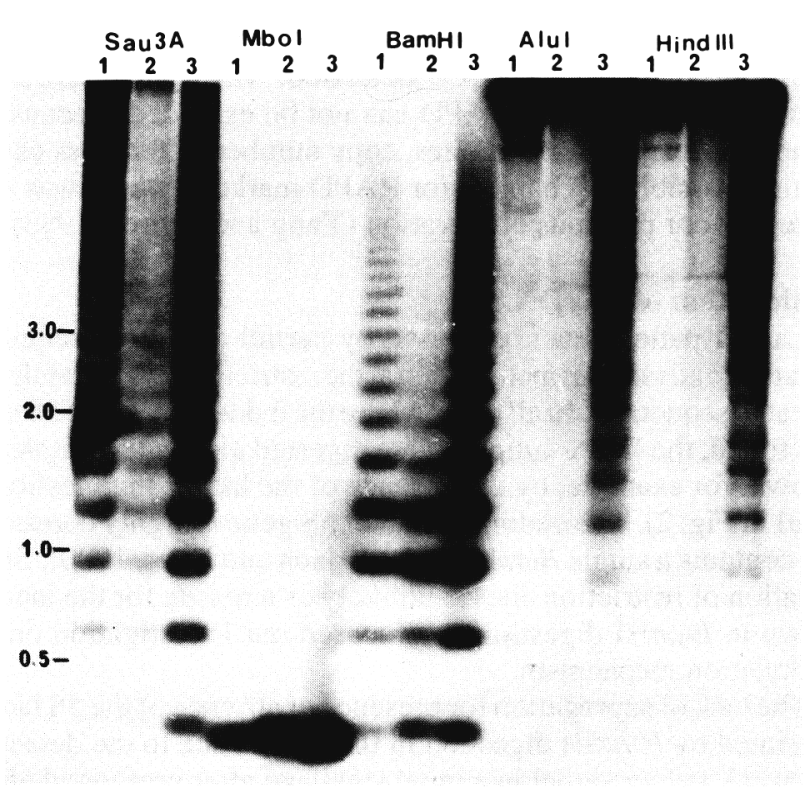

Fig. 2. Hybridization of 5S rDNA with celery genomic DNA digested with different restriction enzymes. A tandem repeat unit of about 310 bp can be resolved in the BamHI digestion. Bars on the left are DNA size in kb. $1=$ annual smallage, $2=$ $\mathrm{F} 1,3$ = celeriac. 
Table 2. Comparison of level of polymorphism for cDNA and their insert size

\begin{tabular}{lccc}
\hline \hline $\begin{array}{l}\text { Range of cDNA } \\
\text { insert size (kb) }\end{array}$ & $\begin{array}{c}\text { Polymorphic } \\
\text { clones } \\
\text { (no.) }\end{array}$ & $\begin{array}{c}\text { Polymorphic } \\
\text { clones } \\
(\%)\end{array}$ \\
\hline $0.3-0.5$ & 23 & 4 & 17.4 \\
$0.5-1.0$ & 61 & 12 & 19.6 \\
$1.0-1.5$ & 32 & 10 & 31.3 \\
$1.5-2.0$ & 8 & 3 & 36.5 \\
\hline
\end{tabular}

cDNA clones showing RFLP markers, 16 were polymorphic for only one enzyme digestion and the remaining 13 are polymorphic for more than one enzyme digestion. According to these criteria, about $55 \%$ of the RPLP markers we found may be caused by point mutations and the other $45 \%$ may be caused by insertions or deletions. In general, both types of polymorphisms play important roles, varying with species and methodologies used.

The positive correlation between RFLP and size of hybridized restriction fragments observed in this study is another evidence of an insertion or deletion mechanism for RFLP, because if RFLP is generated mostly by nucleotide substitution within restriction sites, no correlation would be expected between RFLP and the size of genomic restriction fragments.

As expected, larger probes hybridize larger regions and detect more polymorphisms than smaller ones. However, the relationship of RFLP and probe size we observed is not proportionally correlated. For example, cDNA probes of 1.5 to $2.0 \mathrm{~kb}$ are three to six times longer than those of 0.3 to $0.5 \mathrm{~kb}$, but the polymorphism levels differ only by l-fold. Furthermore, there was no significant difference in polymorphisms of cDNAs between 0.3 to $0.5 \mathrm{~kb}$ and 0.5 to $1.0 \mathrm{~kb}$, and between 1.0 to $1.5 \mathrm{~kb}$ and 1.5 to $2.0 \mathrm{~kb}$ (Table 2).

$R A P D$ markers. Polymorphisms for this marker can be caused by either base substitutions at the primer sites or insertions or deletions between them. Since none of the tested RAPD bands showed RFLP markers, it is likely that most of the RAPD markers found in this study are due to base substitutions. However, small insertions or deletions and small fragments generated by enzyme digestions may escape RFLP detection. Thus, an insertion or deletion mechanism for RAPD can not be excluded. Because of competition among primer sites, copy number differences can be another possible mechanism for RAPD markers, which was suggested by our previous observation (Yang and Quiros, 1993).

\section{Methylation of 5S rDNA}

Ladder patterns can be caused by partial digestion, sequence variation, and random methylation at the restriction sites of tandemly repeated sequences. In all cases where the ladder pattern of $5 \mathrm{~S}$ gene was found, the DNA samples were digested almost to completion (shown, for example, by the absence of the ladder in digestion of $\mathrm{MboI}$ in Fig. 2). The coding region of $5 \mathrm{~S}$ gene is highly conserved and contains a single BamHI site (Gerlach and Dyer, 1980). Since variation of restriction sites is unlikely as a reason for the ladders shown in BamHI digestion, we focused our investigation on the methylation mechanism.

The lack of segregation for presence or absence of the $5 \mathrm{~S}$ ladder generated by Hind111 digestion in the $\mathrm{F}_{2}$ was due to the detection of a weak ladder signal in annual smallage after prolonged exposure. Huestis et al. (1993) did not detect the HindIII ladder of 5S gene under the experimental conditions they used in annual smallage and segregating progenies. This discrepancy may be due to its low frequency and signal level in the population. Variation of $5 \mathrm{~S}$ signal intensity among the $\mathrm{F}_{2}$ individuals can not be solely explained by different amount of DNA samples loaded, and is most likely caused by the weak ladder pattern contributed by annual smallage. The weak $5 \mathrm{~S}$ ladder resulting from HindIII digestion in the $\mathrm{F}_{1}$ (with prolonged exposure) can be explained by segregation of the ladder in the celeriac parent. Insufficient digestion of the DNA sample is very unlikely as the reason. This result shows that annual smallage has not completely lost its Hind 111 sites in the $5 \mathrm{~S}$ gene during its divergence from other cultivated types.

From the analysis of hybridization using BamHI, MboI, and Sau3A digestions, we concluded that the methylation site is the 5' $\mathrm{C}$ in BamHI site GGATCC. Methylation at the cytosine of sequence GATC in the $5 \mathrm{~S}$ gene has been observed in other species, such as wheat (Dvorak et al., 1989). This genomic feature is also very well conserved in celery species, at least in celeriac and annual smallage land races. Based on the results of AluI and Hind111 digestions, it was concluded that the $\mathrm{C}$ residue in HindIII site AAGCTT is methylated. The variation observed for the HindIII 5S ladder may be due to the presence of Hind111 site in the spacer region, where mutation is much more frequent. Lack of the HindIII site in 5S coding regions observed in other plants, such as Vigna radiata, Matthiola incana (Hemleben and Werts, 1988), maize (Mascia et al., 1981) and tomato (Lapitan et al., 1991), supports this conjecture.

In conclusion, our data, along with that of previous studies based on RFLPs and 18S-28S rRNA genes (Huestis, 1992; Huestis et al., 1993), suggest that celery is a true diploid species with a low level of polymorphism among cultivars. This report on estimating sequence composition in the celery genome may provide information for choosing different types of markers for map construction and subsequent marker-aided selection and cloning.

\section{Literature Cited}

Arus, P. and T.J. Orton. 1984. Inheritance patterns and linkage relationships of eight genes in celery. J. Hered. 75: 11-14.

Catlin, D., 0. Ochoa, S. McCormick, and C.F. Quiros. 1988. Celery transformation by Agrobacterium tumefaciens: Cytological and genetic analysis of transgenic plants. Plant Cell Rpt. 7:100-103.

Dvorak, J., H.B. Zhang, R.S. Kota, and M. Lassner. 1989. Organization and evolution of the 5S ribosomal RNA gene family in wheat and related species. Genome 32:1003-1016.

Emsweller, S.L. 1933. An hereditary pithiness in celery. Amer. Soc. Hort. Sci. Proc. 29:480-485.

Gerlach, W.L. and J.P. Bedbrook. 1979. Cloning and characterization of ribosomal genes from wheat and barley. Nucleic Acids Res. 7:18691885.

Gerlach, W.L. and T.A. Dyer. 1980. Sequence organization of the repeating units in the nucleus of wheat which contain $5 \mathrm{~S}$ rRNA genes. Nucleic Acids Res. 8:4851-4865.

Hemleben, V. and D. Werts. 1988. Sequence organization and putative regulatory elements in the 5S rRNA genes of two higher plants (Vigna radiata and Matthiola incana). Gene 62:165-169.

Hiroe, M.A. 1955. Cytotaxonomic comparison of parsley and celery. Bot. Mag. (Tokyo) 68:201-202.

$\mathrm{Hu}$, J. and C.F. Quiros. 1991. Molecular and cytological evidence of deletions in alien chromosomes for two monosomic addition lines of Brassica campestris-oleracea. Theor. Appl. Genet. 81:221-226.

Huestis, G. 1992. Genetic mapping in celery (Apium graveolens L.) and its wild allies based on restriction fragment length polymorphisms. $\mathrm{PhD}$ diss. Univ. of California, Davis.

Huestis, G., M. MacGrath, and C.F. Quiros. 1993. Development of genetic; markers in celery based on restriction fragment length polymorphisms. Theor. Appl. Genet. 85:889-896.

Lagudah, E.S., B.C. Clare, and S. Appels. 1989. Phylogenetic relationships of Triticum tauschii, the D-genome donor to hexaploid wheat. 4. 
Variation and chromosomal location of 5S DNA. Genome 32:10171025.

Lapitan, N.L.V., M.V. Ganal, and SD. Tanksley. 1991. Organization of the 5S ribosomal RNA genes in the genome of tomato. Genome 34:509514.

Mascia, P.N., I. Rubenstein, R.L. Phillips, A.S. Wang, and L.Z. Xiang. 1981. Localization of the 5S rRNA genes and evidence for diversity in the $5 \mathrm{~S}$ region of maize. Gene 15:7-20.

McCouch, S.R., G. Kochert, Z.H. Yu, Z.Y. Wang, G.S. Khush, W.R. Coffman, and S.D. Tanksley. 1988. Molecular mapping of rice chromosomes. Theor. Appl. Genet. 76:815-829.

Murata, M. and T.J. Orton. 1984. G-band-like difference in mitotic prometaphase chromosomes of celery. J. Hered. 75:225-228.

Orton, T.J. 1983. Celery and celeriac. In: W.R. Sharp, D.D. Evans, and P. Amirato (eds.). Handbook of plant cell culture. McMillan, New York. Pope, D.T. and H.M. Munger. 1953a. The inheritance of susceptibility to boron deficiency in celery. Proc. Amer. Soc. Hort. Sci. 61:481-186.

Pope, D.T. and H.M. Munger. 1953b. Heredity and nutrition in relation to magnesium deficiency chlorosis in celery. Proc. Amer. Soc Hort. Sci.
61:472-480.

Quiros, C.F., A. Rugama, Y.Y. Dong, and Y.J. Orton. 1986. Cytological and genetical studies of a male sterile celery. Euphytica 35:867-875.

Quiros, C.F., D. Douches, and V. D'Antonio. 1987. Inheritance of annual habit in celery: Cosegregation with isozyme and anthocyanin markers. Theor. Appl. Genet. 74:203-208.

Rafalski, J., M. Wiewiorowski, and D. Soll. 1982. Organization and nucleotide sequence of nuclear 5S rDNA genes in yellow lupin (Lupinus luteus). Nucleic Acids Res. 10:7635-7642.

Townsend, G.R., R.A. Emerson, and A.G. Newhall. 1946. Resistance to Cercospora apii Fres. in celery (Apium graveolens var. dulce). Phytopathology 36:980-982.

Williams, J.G.K., M.K. Hanafey, J.A. Rafalski, and S.V. Tingey. 1993. Genetic analysis using random amplified polymorphic DNA markers. Methods Enzymol. 218:704-740.

Yang, X. and C.F. Quiros. 1993. Identification and classification of celery cultivars with RAPD markers. Theor. Appl. Genet. 86:205-212.

Yang, X. and C.F. Quiros. 1995. Construction of a genetic linkage map in celery using DNA-based markers. Genome 38:36-44. 